\title{
IMPROVEMENT OF CANOLA SEED YIELD AND QUALITY USING SULPHUR AND IRRIGATION INTERVALS UNDER DIFFERENT IRRIGATION WATER SALINITY LEVELS
}

\author{
Al-Solimani ${ }^{1}$, S.G.; F.S. El-Nakhlawy ${ }^{1}$ and M.H. Al-Morshdy ${ }^{1}$ \\ 1- Arid Land Agriculture Department, Faculty of Meteorology, Environment and Arid Land \\ Agriculture, King Abdul-Aziz University, Jeddah, Saudi Arabia
}

Keywords: Caniola seeds, Sulfur, Fertilization, Irrigation intervals

\section{ABSTRACT}

This investigation was conducted at Hada Elsham Experimental Research Station, King AbdulAziz University during 2007/2008 and 2008/2009 seasons, to study the effects of two irrigation water salinity levels (1200 mg/L and $10000 \mathrm{mg} / \mathrm{L})$, three irrigation water intervals (3, 6 and 9 days) and three sulphur fertilizer rates $(0.0,4.0$ and $6.0 \mathrm{t} / \mathrm{ha})$ on seed yield, yield components and seed quality of canola, Pactole cv. The obtained results showed that seed yield $\mathrm{kg} / \mathrm{ha}$ was significantly increased under the $1200 \mathrm{mg} / \mathrm{L}$ irrigation water and $6 \mathrm{t} / \mathrm{ha}$ of sulphur more than the seed yield/ha under the effect of $1200 \mathrm{mg} / \mathrm{L}$ irrigation water with $4 \mathrm{t} / \mathrm{ha}$ sulphur or $10,000 \mathrm{mg} / \mathrm{L}$ irrigation water with $6 \mathrm{t} / \mathrm{ha}$ sulphur with no significant differences between the two later treatments. Irrigation every 3 days significantly dominated over the irrigation every 6 or 9 days on seed yield and yield components. Irrigation with $10.000 \mathrm{mg} / \mathrm{L}$ salinity water significantly decreased No. of branches /plant, No. of fruit/plant and seed weight/ plant. Besides, Protein content of the seed as well as oil content increased as water salinity increased in both seasons. As sulphur fertilizer rate increased seed yield, yield components protein and oil contents of seed significantly increased, in the two studied seasons. 